\title{
Structure of molybdenum oxide supported on silica SBA-15 studied by Raman, UV-Vis and X-ray absorption spectroscopy
}

\author{
J. P. Thielemann ${ }^{\mathrm{a}, \mathrm{b}}$, T. Ressler ${ }^{\mathrm{c}}$, A. Walter ${ }^{\mathrm{c}}$, G. Tzolova-Müller ${ }^{\mathrm{a}}$, C. Hess ${ }^{\mathrm{b}}$ * \\ ${ }^{a}$ Fritz-Haber-Institut der Max-Planck-Gesellschaft, Abteilung Anorganische Chemie, Faradayweg 4-6, \\ 14195 Berlin, Germany \\ ${ }^{\mathrm{b}}$ Eduard-Zintl-Institut für Anorganische und Physikalische Chemie, Technische Universität Darmstadt, \\ Petersenstraße 20, 64287 Darmstadt, Germany, \\ ${ }^{\mathrm{c}}$ Institut für Chemie, Technische Universität Berlin, Straße des 17 Juni 135, 10623 Berlin, Germany
}

* Corresponding author: e-mail hess@pc.chemie.tu-darmstadt.de,

Received 19 January 2011; Available online 16 March; Published in print 31 May 2011

\begin{abstract}
The structure of molybdenum oxide supported by silica SBA-15 has been studied by visible Raman spectroscopy, diffuse reflectance UV-Vis spectroscopy and X-ray absorption spectroscopy in the dehydrated state obtained after thermal treatment at elevated temperatures $\left(\geq 350^{\circ} \mathrm{C}\right)$. No dependence of the molybdenum oxide structure on preparation procedure or loading has been observed within the range of loadings studied in detail $\left(0.2\right.$ to $\left.0.8 \mathrm{Mo} / \mathrm{nm}^{2}\right)$. X-ray absorption spectroscopy (XAS) reveals that the dehydrated state consists of a mixture of monomeric and connected molybdenum oxide centres. While the presence of crystalline $\mathrm{MoO}_{3}$ can be excluded by Raman spectroscopy, tetrahedrally and octahedrally coordinated $\mathrm{MoO}_{4}$ and $\mathrm{MoO}_{6}$ units are identified by XAS. The $\mathrm{MoO}_{6}$ units possess connectivity similar to that of $\mathrm{MoO}_{3}$ building blocks, whereas the $\mathrm{MoO}_{4}$ units are isolated or connected to other $\mathrm{Mo}_{\mathrm{x}} \mathrm{O}_{\mathrm{y}}$ units. These results are supported by UV-Vis spectra showing intensity at wavelengths $(>300 \mathrm{~nm})$ typical for dimeric and/or oligomeric species.
\end{abstract}

Keywords: molybdenum oxide, structure, supported, silica, SBA-15, Raman, UV-Vis, XAS

\section{Introduction}

Supported molybdenum oxide catalysts have been studied for numerous reactions like partial oxidation reactions of alcohols [1,2], ethers [3], alkanes and olefins [4-6], metathesis reactions $[7,8]$ and the selective catalytic reduction (SCR) of nitric oxide [9,10]. Previous studies have shown that the catalytic properties may depend on the molybdenum oxide structure as well as the choice of the support material [3, 11-13]. For a detailed understanding of supported molybdenum oxide catalysts one strategy may be to separate the effects of the molybdenum oxide structure from those of the support material. Focusing on the structural aspects first it may be desirable to use a support which serves as an 'inert' platform for the deposit. To this end, silica seems to be the material of choice considering its weak interaction with molybdenum oxide and irreducibility. It should be pointed out, however, that despite the relatively inert behavior of silica the detailed state of the deposited supported molybdenum oxide may still depend on a variety of parameters such as silica material and its pre-treatment, the synthesis procedure etc.

For highly dispersed molybdenum oxide supported on silica a hydrated and a dehydrated state have to be distinguished. The hydrated state is present when the sample is exposed to moisture under ambient conditions. If the sample is treated in dry synthetic air at elevated temperatures $\left(\geq 350^{\circ} \mathrm{C}\right)$, the molybdenum oxide is converted into a dehydrated state [14].

In the literature, the structure of silica supported molybdenum oxides in the dehydrated state is still debated. First the main literature results on silica SBA-15 supported systems will be summarized [15-20]. Lou et al. studied dispersed molybdenum oxides supported on SBA-15 with densities within 0.3-1.1 Mo/nm² using TPR, Raman and UV-Vis spectroscopy and reported the presence of mono- 
meric beside oligomeric molybdenum oxide species at a density of $1.1 \mathrm{Mo} / \mathrm{nm}^{2}$ [17]. Furthermore, it was concluded that the two Raman bands of the molybdenyl stretching vibration at 970 and $985 \mathrm{~cm}^{-1}$ are associated with molybdenum oxide species of different size [17]. Ressler et al. concluded on the basis of EXAFS and Raman results that on SBA-15 supported molybdenum oxide $\left(0.9 \mathrm{Mo} / \mathrm{nm}^{2}\right)$ hexagonal $\mathrm{MoO}_{3}$ like species should be present, besides traces of $\alpha-\mathrm{MoO}_{3}[15,16]$. In contrast, Balcar et al. reported on the basis of Raman spectra that isolated dioxo molybdenum oxide species were present at a density of $0.8 \mathrm{Mo} / \mathrm{nm}^{2}$ [20]. Recently, the existence of dimeric/oligomeric besides monomeric molybdenum oxide species has been reported for silica SBA-15 at Mo densities of 0.8 and $2.2 \mathrm{Mo} / \mathrm{nm}^{2}$ using IR spectroscopy [21].

Regarding silica-based molybdenum oxide systems in general the following results can be found in the literature [22-29]. For Cabosil and Silicyle supported molybdenum oxide it was reported on the basis of Raman and X-ray absorption spectroscopic results that within 0.1 to 0.8 $\mathrm{Mo} / \mathrm{nm}^{2}$ exclusively isolated molybdenum oxide species should be present in the dehydrated state. To this end, the discussion in the literature mainly focuses on the question whether isolated dioxo, monooxo or octahedral centres are present on the support [22-27]. However, UV-Vis spectra of dehydrated molybdenum oxide possess intensity at wavelengths well above $300 \mathrm{~nm}$ indicating that also oligomeric species are present on silica supported molybdenum oxides at Mo densities below $1.0 \mathrm{Mo} / \mathrm{mm}^{2}[18,30,31]$. Also Iwasawa et al. described a dimeric molybdenum oxide structure $\left(0.1\right.$ and $\left.0.3 \mathrm{Mo} / \mathrm{nm}^{2}\right)$ to be present on silica using EXAFS and $\mathrm{H}_{2}$ reduction experiments [28,29]. Summarizing, the above literature survey clearly shows that the structure of molybdenum oxide supported by silica is still a matter of debate.

In this study we investigate the structure of silica SBA-15 supported molybdenum oxides $\left(\mathrm{Mo}_{\mathrm{x}} \mathrm{O}_{\mathrm{y}} / \mathrm{SBA}-15\right)$ by Raman, UV-Vis and X-ray absorption spectroscopy focusing on low molybdenum densities $\left(\leq 0.8 \mathrm{Mo} / \mathrm{nm}^{2}\right)$. SBA-15 was chosen as a support material as it provides a high specific surface area and a well-defined pore structure. A grafting/ion-exchange procedure, which has previously been successfully used to prepare SBA-15 supported vanadium oxide catalysts system [32] is applied for the first time to supported molybdenum oxides. As the molybdenum oxide precursor is held electrostatically within the channels of the mesoporous matrix in a prearranged geometry, this method allows one to precisely control the amount and dispersion of the metal oxide introduced into SBA-15 within a broad range of densities. Recently, by such an approach new insight into the structure of silica SBA-15 supported vanadium oxide catalysts has been obtained [3236].

\section{Experimental}

\subsection{Synthesis.}

SBA-15 was synthesized as described in the literature [37,38] and functionalized with 3aminopropyltrimethoxysilane (APTMS) according to a procedure developed by Hess et al. [34,39]. For the subsequent ion exchange $2.0 \mathrm{~g}$ of functionalized SBA-15 was suspended in $60 \mathrm{ml}$ distilled water. To obtain a sample with $5.9 \mathrm{wt} \%$ Mo loading $183 \mathrm{mg}$ ammonium heptamolybdate (AHM) was added to the suspension and stirred for $12 \mathrm{~h}$. At the end of the ion exchange the suspension containing AHM and functionalized SBA-15 had a $\mathrm{pH}$ value of 4.0. Based on Raman analysis at this $\mathrm{pH}$ the majority of isopolymolybdates is present as heptamolybdate anions $\left(\mathrm{Mo}_{7} \mathrm{O}_{24}{ }^{6-}\right)$ in solution. The product was filtered and washed with water. Afterwards it was dried overnight at room temperature and calcined for $12 \mathrm{~h}$ at $550^{\circ} \mathrm{C}$.

A SBA-15 reference sample was synthesized according to the above procedure with the difference that in the ion-exchange step potassium oxalate monohydrate was used instead of ammonium heptamolybdate. This sample will be referred to as SBA-15 (ox).

For the sample prepared by incipient wetness impregnation $186 \mathrm{mg}$ molybdenum acetylacetonate $\left(\mathrm{MoO}_{2}(\mathrm{acac})_{2}\right)$ was dissolved in $18 \mathrm{ml}$ ethanol and subsequently mixed with $4.0 \mathrm{~g}$ of bare SBA-15 yielding a Mo loading of $5.5 \mathrm{wt} \%$. Then the sample was dried overnight at room temperature and afterwards calcined for $12 \mathrm{~h}$ at $550^{\circ} \mathrm{C}$.

\subsection{Physical characterization.}

The nitrogen adsorption/desorption isotherms were measured on a Quantachrome Autosorb-1 surface analyzer. Before the experiment the samples were pretreated in vacuum at $80^{\circ} \mathrm{C}$ for $16 \mathrm{~h}$. The specific surface area of the samples was measured by standard multipoint BET [40] analysis with a $\mathrm{N}_{2}$ cross section of $13.5 \AA^{2}$ [41]. The pore volume was determined from the adsorption branch of the isotherm at a $\mathrm{p} / \mathrm{p}_{0}$ ratio of 0.95 . The pore-size distribution was calculated by the DFT method using the desorption branch of the isotherm. The molybdenum content of the $\mathrm{Mo}_{\mathrm{x}} \mathrm{O}_{\mathrm{y}} / \mathrm{SBA}-15$ sample was determined by XRF and EDX. Results from Raman spectroscopy, XPS and thermal analysis demonstrate that after calcination of the ion-exchanged samples all framework constituents were removed from the silica matrix. 


\subsection{Raman spectroscopy.}

The Raman spectra were measured using an argon ion laser (Melles Griot) at $514 \mathrm{~nm}$ and an excitation power of $6 \mathrm{~mW}$ measured at the position of the sample. The Raman spectrometer is based on a transmissive spectrometer equipped with a CCD detector and a spectral resolution of 5 $\mathrm{cm}^{-1}$ (Kaiser Optical, HL5R). In situ Raman spectra of the dehydrated sample were recorded after treatment in synthetic air at $350^{\circ} \mathrm{C}$ for $30 \mathrm{~min}$ and subsequent cooling to room temperature. Typical accumulation times were 30 min. The $\mathrm{Mo}_{\mathrm{x}} \mathrm{O}_{\mathrm{y}} / \mathrm{SBA}-15$ samples used for EXAFS analysis were tested in an in situ Raman cell operated at $500^{\circ} \mathrm{C}$ in synthetic air $(50 \mathrm{ml} / \mathrm{min})$. For Raman experiments the samples were pressed at $70 \mathrm{MPa}$ and sieved to obtain a fraction of particle sizes between 250 and $355 \mu \mathrm{m}$. Typical accumulation times for these spectra were $120 \mathrm{~min}$.

\subsection{UV-Vis spectroscopy.}

Diffuse reflectance UV-Vis spectra were measured using a Perkin-Elmer Lambda 950 spectrometer equipped with a Harrick diffuse reflectance attachment and a reaction chamber. As light sources a tungsten-halogen and a deuterium lamp were used. Spectra have been acquired from 200 to $800 \mathrm{~nm}$. The samples were dehydrated in situ by heating at a rate of $10 \mathrm{~K} / \mathrm{min}$ up to $450^{\circ} \mathrm{C}$ in $20 \% \mathrm{O}_{2}$ and $80 \% \mathrm{~N}_{2}$, held for $30 \mathrm{~min}$ at $450^{\circ} \mathrm{C}$ and subsequently cooled to room temperature. During the dehydration treatment spectra were recorded in 5 min intervals. $\mathrm{BaSO}_{4}$ was used as white standard. The samples used for the UV-Vis experiments are from a different batch than those used for Raman spectroscopy. As a result the Mo densities of the two series of samples deviate slightly from each other due to the batch-tobatch variation in the specific surface area values $( \pm 5 \%)$.

\subsection{X-ray absorption spectroscopy (XAS).}

Transmission XAS experiments were performed at the Mo K edge at beamline X at the Hamburg Synchrotron Radiation Laboratory, HASYLAB, using a Si(311) double crystal monochromator (measuring time $\sim 4 \mathrm{~min} / \mathrm{scan}$ ). In situ experiments were conducted in a flow-reactor at atmospheric pressure (5 vol-\% oxygen in $\mathrm{He}$, total flow $\sim 30$ $\mathrm{ml} / \mathrm{min}$, temperature range from $27^{\circ} \mathrm{C}$ to $400^{\circ} \mathrm{C}$, heating rate $4 \mathrm{~K} / \mathrm{min}$ ). The gas phase composition at the cell outlet was continuously monitored using a non-calibrated mass spectrometer in a multiple ion detection mode (Omnistar from Pfeiffer). Reference oxides were mixed with boron nitride ( $7 \mathrm{mg}$ each with $30 \mathrm{mg} \mathrm{BN})$ while SBA-15 materials $(\sim 50 \mathrm{mg})$ were used as-is. Powders were pressed with a force of 1 ton into a $5 \mathrm{~mm}$ in diameter pellet resulting in an edge jump at the Mo K-edge of $\Delta \mu_{\mathrm{x}} \sim 1$.

$\mathrm{X}$-ray absorption fine structure (XAFS) analysis was performed using the software package WinXAS v3.2 [42].
Background subtraction and normalization were carried out by fitting linear polynomials to the pre-edge and $3^{\text {rd }}$ degree polynomials to the post-edge region of an absorption spectrum, respectively. The extended X-ray absorption fine structure (EXAFS) $\chi(\mathrm{k})$ was extracted by using cubic splines to obtain a smooth atomic background $\mu_{0}(\mathrm{k})$. The $\mathrm{FT}\left(\chi(\mathrm{k}) \cdot \mathrm{k}^{3}\right)$, often referred to as pseudo radial distribution function, was calculated by Fourier transforming the $\mathrm{k}^{3}$ weighted experimental $\chi(\mathrm{k})$ function, multiplied by a Bessel window, into the $\mathrm{R}$ space.

EXAFS data analysis was performed using theoretical backscattering phases and amplitudes calculated with the ab-initio multiple-scattering code FEFF7 [43]. Structural data employed in the analyses were taken from the Inorganic Crystal Structure Database (ICSD). Single scattering and multiple scattering paths in the hexagonal $\mathrm{MoO}_{3}$ model structure were calculated up to $6.0 \AA$ with a lower limit of $4.0 \%$ in amplitude with respect to the strongest backscattering path. EXAFS refinements were performed in $\mathrm{R}$ space simultaneously to magnitude and imaginary part of a Fourier transformed $\mathrm{k}^{3}$-weighted and $\mathrm{k}^{1}$-weighted experimental $\chi(\mathrm{k})$ using the standard EXAFS formula [33]. This procedure strongly reduces the correlation between the various XAFS fitting parameters. Structural parameters allowed to vary in the refinement were (i) disorder parameter $\sigma^{2}$ of selected single-scattering paths assuming a symmetrical pair-distribution function and (ii) distances of selected single-scattering paths. The statistical significance of the fitting procedure employed was carefully evaluated [44] according to procedures recommended by the International X-ray Absorption Society on criteria and error reports [45]. First, the number of independent parameters $\left(\mathrm{N}_{\text {ind }}\right)$ was calculated according to the Nyquist theorem $\mathrm{N}_{\text {ind }}=2 / \pi$ $\cdot \Delta \mathrm{R} \cdot \Delta \mathrm{k}+2$. In all cases the number of free running parameters in the refinements was well below $\mathrm{N}_{\text {ind. }}$. Second, confidence limits were calculated for each individual parameter [44]. Third, a so-called $\mathrm{F}$ test was performed to assess the significance of the effect of additional fitting parameters on the fit residual [46].

\section{Results and discussion}

A summary of the physisorption characterization of SBA-15 and SBA-15 supported molybdenum oxide samples is given in Table 1. The functionalization step with organic silane APTMS is accompanied by the generation of extra silica on the pore wall [47]. This results in smaller specific surface areas for $\mathrm{Mo}_{\mathrm{x}} \mathrm{O}_{\mathrm{y}} / \mathrm{SBA}-15$ samples prepared by grafting/ion-exchange as compared to those synthesized by incipient wetness impregnation. However, as a benefit of the deposition of extra silica a (hydro)thermally and mechanically more stable material is obtained [47]. With increasing molybdenum oxide loading the surface area and pore volume of the samples significantly drops indicating that the molybdenum oxide is located inside the porous matrix (see Table 1) 
Table 1: Surface and porosity characteristics of the $\mathrm{Mo}_{\mathrm{x}} \mathrm{O}_{\mathrm{y}} / \mathrm{SBA}-15$ samples and bare SBA-15

\begin{tabular}{|c|c|c|c|c|c|c|}
\hline Sample & Preparation & Mo loading (wE) & Mo density (atoms/nm²) & $\operatorname{Sect}\left(m^{2} / g\right)$ & $d,(\dot{A})$ & $V_{p}\left(\mathrm{~cm}^{2} / g\right)$ \\
\hline SBA-15 & - & 0.0 & 0.0 & 770 & 73 & 1.00 \\
\hline SBA-15(ox) & Ion exchange & 0.0 & 0.0 & 408 & 62 & 0.50 \\
\hline \multirow{7}{*}{$\mathrm{M}_{2} \mathrm{O}_{\sqrt{ }} \sqrt{\mathrm{SBA}-15}$} & lon exchange & 1.0 & 0.2 & 520 & 63 & 0.6 \\
\hline & & 5.9 & 0.8 & 422 & 63 & 0.55 \\
\hline & & 8.4 & 1.5 & 345 & 70 & 0.46 \\
\hline & & 11.0 & 2.4 & 294 & 70 & 0.45 \\
\hline & & 12.1 & 3.5 & 217 & 69 & 0.35 \\
\hline & & 13.9 & 6.8 & 130 & 70 & 0.27 \\
\hline & Incipient wetness & 5.5 & 0.6 & 596 & 70 & 0.80 \\
\hline
\end{tabular}

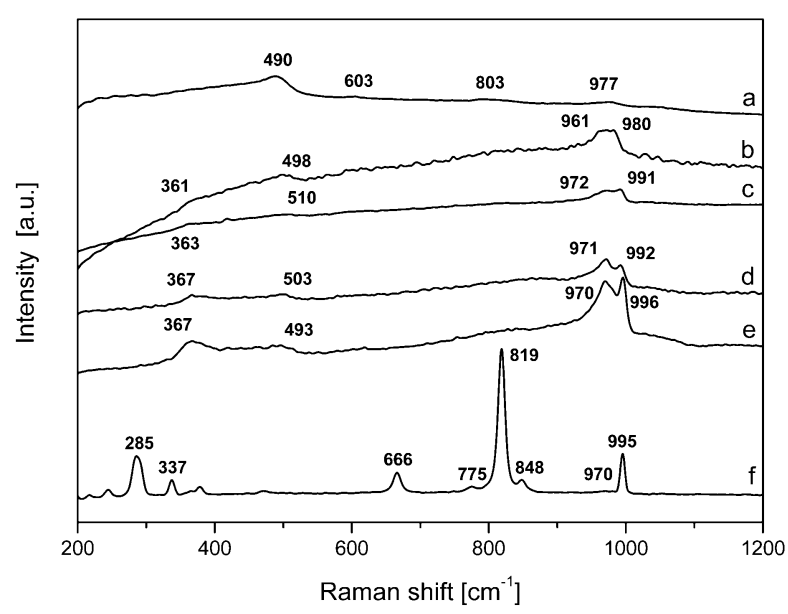

Fig. 1: Room temperature Raman spectra of dehydrated (a) SBA15 (ox) and $\mathrm{Mo}_{\mathrm{x}} \mathrm{O}_{\mathrm{y}} / \mathrm{SBA}-15$ samples with Mo loadings of (b) 5.9 wt $\% ; 0.8 \mathrm{Mo} / \mathrm{nm}^{2}$, (c) $8.4 \mathrm{wt} \% ; 1.5 \mathrm{Mo} / \mathrm{nm}^{2}$, (d) $11.0 \mathrm{wt} \% ; 2.4$ $\mathrm{Mo} / \mathrm{nm}^{2}$, (e) $12.1 \mathrm{wt} \% ; 3.5 \mathrm{Mo} / \mathrm{nm}^{2}$ and (f) $13.9 \mathrm{wt} \% ; 6.8 \mathrm{Mo} / \mathrm{nm}^{2}$. The spectra are offset for clarity.

In the following the Raman results will be discussed. Figure 1 depicts Raman spectra of dehydrated $\mathrm{Mo}_{\mathrm{x}} \mathrm{O}_{\mathrm{y}} / \mathrm{SBA}-15$ samples at different molybdenum loadings in comparison to bare SBA-15, respectively. Previously, Raman spectroscopy has been shown to be a very sensitive indicator for the presence of crystalline $\mathrm{MoO}_{3}[21,48]$. Interestingly, for the $\mathrm{Mo}_{\mathrm{x}} \mathrm{O}_{\mathrm{y}} / \mathrm{SBA}-15$ samples prepared by ion exchange the onset of crystalline $\mathrm{MoO}_{3}$ formation is observed at a higher molybdenum densities $\left(\geq 3.5 \mathrm{Mo} / \mathrm{nm}^{2}\right)$ as compared to other silica-supported systems prepared by impregnation techniques $\left(\leq 1.1 \mathrm{Mo} / \mathrm{nm}^{2}\right)[16,17,22]$. The origin of this behaviour can be ascribed to the better control of the precursor dispersion on the functionalized support during synthesis [32].

As shown in Fig. 1 the room temperature Raman spectra of dehydrated $\mathrm{Mo}_{\mathrm{x}} \mathrm{O}_{\mathrm{y}} / \mathrm{SBA}-15$ samples up to Mo loadings of $12.1 \mathrm{wt} \%$ are characterized by major bands at around 990, 970, 500 and $360 \mathrm{~cm}^{-1}$ [49]. First the contribution of the bare support material will be discussed (see spectrum a). SBA-15 shows an intense band around 500 $\mathrm{cm}^{-1}$, which is attributed to cyclic tetrasiloxane rings (D1 defect mode) [50]. The weaker bands around 600, 800 and at $977 \mathrm{~cm}^{-1}$ are assigned to cyclic trisiloxane rings (D2

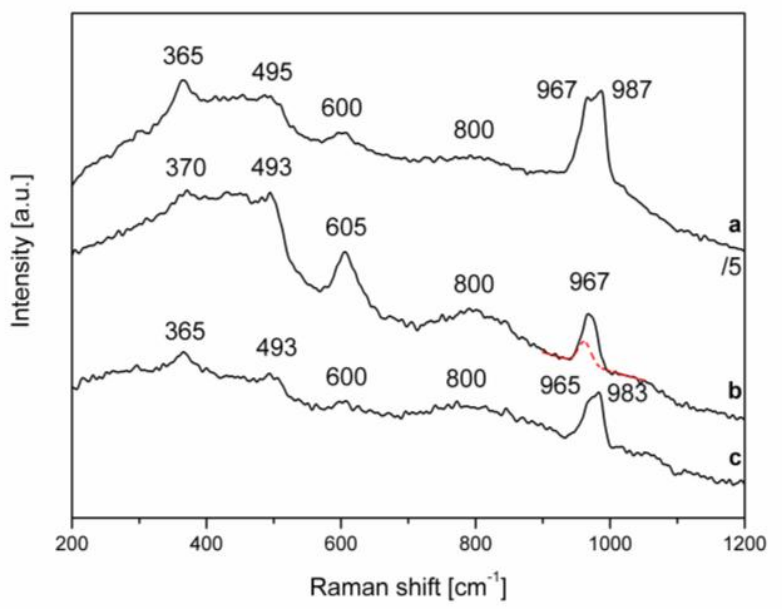

Fig. 2: Raman spectra of $\mathrm{Mo}_{\mathrm{x}} \mathrm{O}_{\mathrm{y}} / \mathrm{SBA}-15$ samples at $500^{\circ} \mathrm{C}$ in $\mathrm{N}_{2} / \mathrm{O}_{2}$ (80:20) flow at $50 \mathrm{ml} / \mathrm{min}$ (a) $5.9 \mathrm{wt} \% \mathrm{Mo} ; 0.8 \mathrm{Mo} / \mathrm{nm}^{2}$; (b) $1.0 \mathrm{wt} \% \mathrm{Mo} ; 0.2 \mathrm{Mo} / \mathrm{nm}^{2}$ (Fit of the Si-OH stretching (dotted red)) and (c) $5.5 \mathrm{wt} \% \mathrm{Mo} ; 0.6 \mathrm{Mo} / \mathrm{nm}^{2}$ (incipient wetness). The spectra are offset for clarity.

defect mode), the symmetrical $\mathrm{Si}-\mathrm{O}-\mathrm{Si}$ and the $\mathrm{Si}-\mathrm{OH}$ stretching mode, respectively [50-53]. The Raman band at around $360 \mathrm{~cm}^{-1}$ can be attributed to Mo-O bending [54,55]. Furthermore, the two bands between 960 and $970 \mathrm{~cm}^{-1}$ and between 980 and $996 \mathrm{~cm}^{-1}$ are assigned to molybdenyl stretching modes, respectively [17,22,27]. At low loading, i.e. for $5.9 \mathrm{wt} \% \mathrm{Mo}\left(0.8 \mathrm{Mo} / \mathrm{nm}^{2}\right)$, the molybdenyl stretching modes exhibit a flat top from 961 to 980 $\mathrm{cm}^{-1}$. With increasing Mo loading a new band appears at $991 \mathrm{~cm}^{-1}$, which shifts up to $996 \mathrm{~cm}^{-1}$. Up to a Mo loading of $12.1 \mathrm{wt} \%\left(3.5 \mathrm{Mo} / \mathrm{nm}^{2}\right)$, there is no indication for the formation of crystalline $\mathrm{MoO}_{3}$. At higher Mo loadings the characteristic bands of crystalline $\alpha-\mathrm{MoO}_{3}$ e.g. at 819 and $995 \mathrm{~cm}^{-1}$ are clearly observed. Besides, the bands at 775 and $848 \mathrm{~cm}^{-1}$ are due to small amounts of $\beta^{6}-\mathrm{MoO}_{3}$ [48], as confirmed by XRD and electron diffraction (not shown).

Figure 2 depicts spectra of dehydrated $\mathrm{Mo}_{\mathrm{x}} \mathrm{O}_{\mathrm{y}} / \mathrm{SBA}$ 15 samples at $500^{\circ} \mathrm{C}$ in dry flowing air. Below $900 \mathrm{~cm}^{-1}$ the bands appear at the same positions as in case of the room temperature spectra (see Fig. 1). As shown in Figure 2 the region of the molybdenyl band of the sample with a Mo density of $0.8 \mathrm{Mo} / \mathrm{nm}^{2}$ (spectrum a) is characterized by a splitting into two components at 967 and $987 \mathrm{~cm}^{-1}$. For comparison, in case of the sample prepared by incipient 
wetness impregnation $\left(0.6 \mathrm{Mo} / \mathrm{nm}^{2}\right.$, spectrum c) the molybdenyl bands appear at very similar positions $\left(965 \mathrm{~cm}^{-1}\right.$, $\left.983 \mathrm{~cm}^{-1}\right)$. Therefore, the effect of the preparation procedure on the formed molybdenum oxide structures appears to be small. If the Mo density is further decreased to 0.2 $\mathrm{Mo} / \mathrm{nm}^{2}$ only one band with asymmetric shape is observed at $967 \mathrm{~cm}^{-1}$. Normalising the Raman spectrum of SBA-15 (ox) recorded at $500^{\circ} \mathrm{C}$ under dehydrated conditions to the silica-related bands at 605 and $800 \mathrm{~cm}^{-1}$ of spectrum (b) shows that the $967 \mathrm{~cm}^{-1}$ band comprises a contribution of the Si-OH stretching mode at $965 \mathrm{~cm}^{-1}$. As reference Fig. 2 shows the intensity of the $\mathrm{Si}-\mathrm{OH}$ stretching mode for bare SBA-15 as dotted line. Its contribution to spectrum $b$ will be reduced as a result of anchoring of molybdenum oxide species to the support but will be still significant because of the small Mo density $\left(0.2 \mathrm{Mo} / \mathrm{nm}^{2}\right)$ as compared to the $\mathrm{OH}$ density of SBA-15 determined by NMR (3.7 OH/nm²) [56].

Previously, on the basis of DFT calculations the two bands at 967 and $987 \mathrm{~cm}^{-1}$ have been assigned to the asymmetric and symmetric modes of a tetrahedral dimolybdenyl species [24]. Furthermore, a third mode at $1020 \mathrm{~cm}^{-1}$ was observed and assigned to the molybdenyl vibration of a square pyramidal molybdenum oxide centre [31]. In a recent DFT study Gregoriades et al. use a more sophisticated, larger model to simulate silica supported mono molybdenum oxide centres and suggest instead that the assignment of the two bands at 988 and $1020 \mathrm{~cm}^{-1}$ should be reversed [57]. Importantly, according to the latter assignment the two main molybdenyl bands at 967 and 987 $\mathrm{cm}^{-1}$ represent different molybdenum oxide species. An assignment of these two bands to different species is supported by the observation that the presence of steam significantly changes their intensity ratio [58]. While detailed calculations for connected $\mathrm{Mo}_{\mathrm{x}} \mathrm{O}_{\mathrm{y}}$ centres are not available and considering the fact that missing M-O-M Raman signatures do not necessarily mean the absence of connected centres $[33,35,36]$, the visible Raman spectra can not answer the question whether in the dehydrated state the surface molybdenum oxide species consist of isolated centres or connected centres or a mixture of both. Therefore, to gain further structural insight UV-Vis and X-ray absorption spectroscopy were employed.

Figure 3 shows the UV-Vis spectra of dehydrated $\mathrm{Mo}_{\mathrm{x}} \mathrm{O}_{\mathrm{y}} / \mathrm{SBA}-15$ samples for loadings within 5.9 - $13.9 \mathrm{Mo}$ wt $\%\left(0.8-3.2 \mathrm{Mo} / \mathrm{nm}^{2}\right)$. The absorption bands between 200 and $400 \mathrm{~nm}$ can be assigned to ligand to metal charge transfer $(\mathrm{CT})$ transitions $\left(\mathrm{O}^{2-} \rightarrow \mathrm{Mo}^{6+}\right)$ [59]. The maximum of the CT band is almost constant at around $242 \mathrm{~nm}$. Besides, a shoulder at around $280 \mathrm{~nm}$ is visible. With increasing Mo loading no significant change regarding shape and position of the bands is observed. In the following related literature results and assignments will be discussed. Wachs et al., for instance, examined dehydrated Cabosil supported molybdenum oxide within a Mo density range of 0.1 to 2.2 $\mathrm{Mo} / \mathrm{nm}^{2}$ and reported two bands at 230 and $275 \mathrm{~nm}$, which have been assigned to isolated monomeric species $[23,31]$.
The typical shape and band position is also frequently observed at lower densities of $0.1-0.4 \mathrm{Mo} / \mathrm{nm}^{2}$ on other silica supports $[60,61]$.

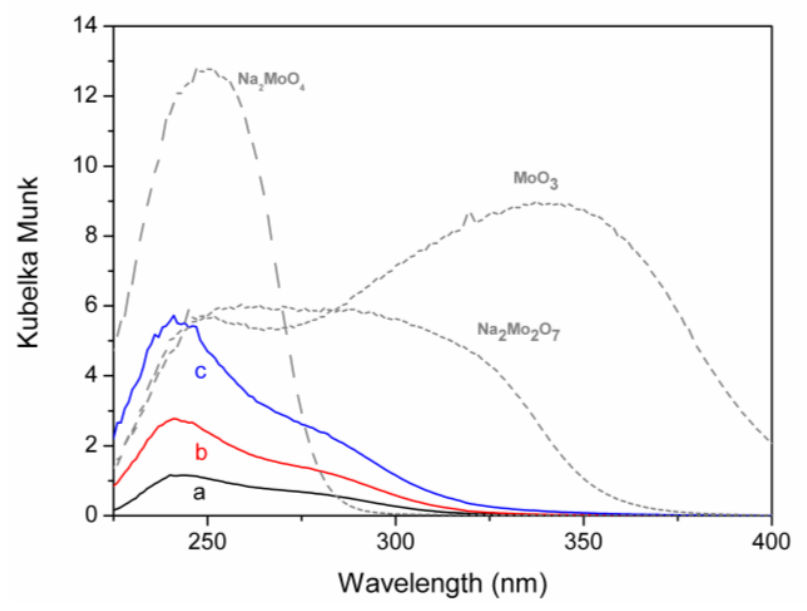

Fig. 3: UV-Vis spectrum of a) $5.9 \mathrm{Mowt} \%\left(0.8 \mathrm{Mo} / \mathrm{nm}^{2}\right)$, b) 11.1 Mo wt $\%\left(2.0 \mathrm{Mo} / \mathrm{nm}^{2}\right)$, c) $13.9 \mathrm{Mo} \mathrm{wt} \%\left(3.2 \mathrm{Mo} / \mathrm{nm}^{2}\right)$ and references $\mathrm{Na}_{2} \mathrm{MoO}_{4}(\mathrm{e}), \mathrm{Na}_{2} \mathrm{Mo}_{2} \mathrm{O}_{7}$ (f) and $\mathrm{MoO}_{3}(\mathrm{~g})$ in the dehydrated state.

The typical shape and band position is also frequently observed at lower densities of $0.1-0.4 \mathrm{Mo} / \mathrm{nm}^{2}$ on other silica supports $[60,61]$.

In the literature, several interpretations of the observed bands for silica supported molybdenum oxides can be found. As reference compounds molybdates like ammonium heptamolybdate, sodium molybdate, sodium dimolybdate and crystalline molybdenum oxide have been used. In addition, comparison with the spectra of species formed in dependence of $\mathrm{pH}$ in aqueous molybdate solutions is quite common. Traditionally, absorption bands from 250 to $280 \mathrm{~nm}$ have been assigned to a tetrahedral and bands from 300 to $330 \mathrm{~nm}$ to an octahedral geometry of isolated molybdenum oxide centres [62]. If also connections between the centres are considered, the expected regions for both geometries may significantly deviate. Jezlorowski and Knözinger assigned the contribution from 230 to $240 \mathrm{~nm}$ to isolated tetrahedrally coordinated Mo centres and the contribution from 250 to $290 \mathrm{~nm}$ to species containing bridging Mo-O-Mo structures [63]. Plyuto et al. attributed the region between 280 and $295 \mathrm{~nm}$ to octahedral species [30], while Song et al. assigned the region around $280 \mathrm{~nm}$ to tetrahedral species in the terminal position of oligomers [6]. Seyedmonir and Howe reported the region at around 275 $\mathrm{nm}$ to be due to tetrahedral species, but were not able to distinguish between isolated and connected molybdenum oxide centres [64].

The above literature discussion shows that there is significant overlap of the spectral regions of tetrahedrally coordinated species (230 to $295 \mathrm{~nm}$ ), [63,65] octahedrally coordinated species (270 to $330 \mathrm{~nm}$ ) [62] and connected molybdenum oxide centres (250 to $290 \mathrm{~nm}$ ) [63]. Thus, on the basis of UV-absorption bands only no clear distinction 


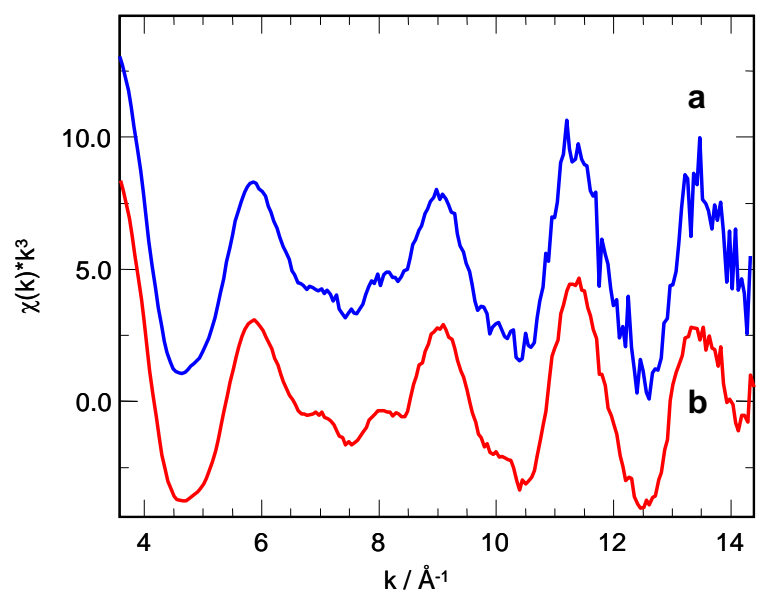

Fig. 4: Mo K edge XAFS $\chi(\mathrm{k})$ of dehydrated $\mathrm{Mo}_{\mathrm{x}} \mathrm{O}_{\mathrm{y}} / \mathrm{SBA}-15$ with (a) $1.0 \mathrm{wt} \% \mathrm{Mo} ; 0.2 \mathrm{Mo} / \mathrm{nm}^{2}$ and (b) $5.5 \mathrm{wt} \% \mathrm{Mo} ; 0.6 \mathrm{Mo} / \mathrm{nm}^{2}$ after thermal treatment in $5 \%$ oxygen in $\mathrm{He}$ at $350^{\circ} \mathrm{C}$. The spectra are offset for clarity.

of the local molybdenum oxide structures is possible $[60,62,66]$. Nevertheless, by comparison with reference substances several exclusions regarding the molybdenum oxide structures present can be made. The spectra of dehydrated $\mathrm{Mo}_{\mathrm{x}} \mathrm{O}_{\mathrm{y}} / \mathrm{SBA}-15$ show significant intensity at higher wavelengths than the spectrum of $\mathrm{Na}_{2} \mathrm{MoO}_{4}$. Thus it appears that even at Mo densities of $0.8 \mathrm{Mo} / \mathrm{nm}^{2}$ other species besides isolated tetrahedral species are present. The additional intensity at wavelengths $\geq 280 \mathrm{~nm}$ can be explained by the presence of a second species, which may be isolated octahedrals, connected tetrahedral or octahedral molybdenum oxide centres or a mixture of any of these species.

Figure 4 shows the XAS $\chi(\mathrm{k})$ data of two dehydrated $\mathrm{Mo}_{\mathrm{x}} \mathrm{O}_{\mathrm{y}} / \mathrm{SBA}-15$ samples (5.5 and $1.0 \mathrm{wt} \%$ Mo loading). The good signal-to-noise ratio of the XAS data of the sample with $5.5 \mathrm{wt} \%$ Mo loading in the k range from 4 to $14 \AA^{-}$ ${ }^{1}$ permitted the detailed XAFS analysis described below. The Mo K near-edge (XANES) spectra of the two dehydrated $\mathrm{Mo}_{\mathrm{x}} \mathrm{O}_{\mathrm{y}} / \mathrm{SBA}-15$ materials containing $1.0 \%$ or 5.5 wt $\%$ Mo are depicted in Fig. 5. The very similar XANES and XAFS region of the spectra in Figures 4 and 5 indicate a similar local structure around the Mo centres in the two samples. In this concentration region the local structure of the Mo oxide species as detected by XAS appears to be independent of the Mo loading. A similar behaviour was reported for vanadium oxide species supported on SBA-15 in a similar concentration range [44,47]. With respect to a detailed structural analysis in the following we focused on the sample with a loading of $5.5 \mathrm{wt} \%$ Mo because of its better XAFS data quality.

The evolution of Mo $\mathrm{K}$ edge Fourier transformed XAFS $\chi(\mathrm{k})$ functions $\left(\mathrm{FT}\left(\chi(\mathrm{k}) \cdot \mathrm{k}^{3}\right)\right)$ of $\mathrm{Mo}_{\mathrm{x}} \mathrm{O}_{\mathrm{y}} / \mathrm{SBA}-15$ during thermal treatment in oxygen are depicted in Fig. 6. Thermal dehydration was performed in the temperature range from $27^{\circ} \mathrm{C}$ to $350^{\circ} \mathrm{C}$ in $5 \%$ oxygen in $\mathrm{He}$ at a heating rate of $5 \mathrm{~K} / \mathrm{min}$. Apparently, loss of water at $\sim 100^{\circ} \mathrm{C}$ is

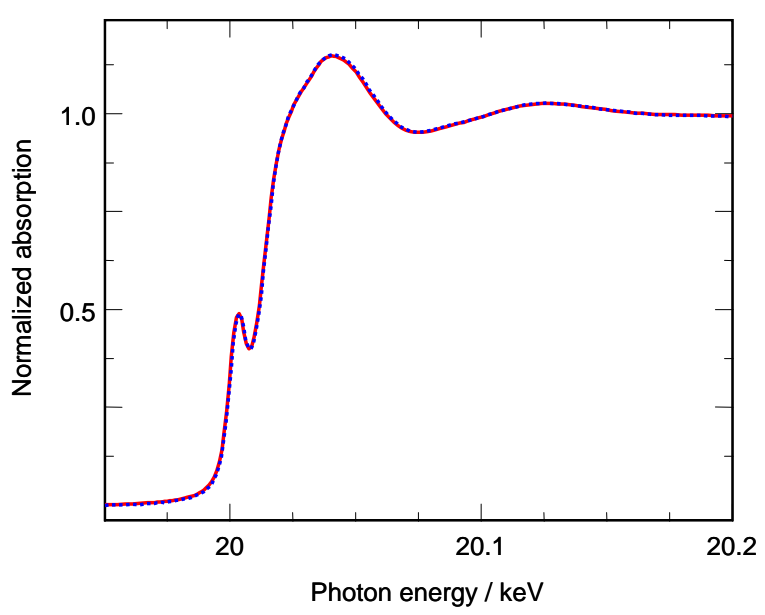

Fig. 5: Mo K edge XANES spectra of dehydrated $\mathrm{Mo}_{\mathrm{x}} \mathrm{O}_{\mathrm{y}} / \mathrm{SBA}-15$ with $5.5 \mathrm{wt} \% \mathrm{Mo} ; 0.6 \mathrm{Mo} / \mathrm{nm}^{2}$ (solid) and $1.0 \mathrm{wt} \% \mathrm{Mo} ; 0.2$ $\mathrm{Mo} / \mathrm{nm}^{2}$ (dotted).

accompanied by a characteristic structural transformation from hydrated $\mathrm{Mo}_{\mathrm{x}} \mathrm{O}_{\mathrm{y}} / \mathrm{SBA}-15$ to dehydrated $\mathrm{Mo}_{\mathrm{x}} \mathrm{O}_{\mathrm{y}} / \mathrm{SBA}-$ 15 [15]. Distinct changes in the first Mo-O coordination sphere indicate a change in Mo-O distance distribution or coordination geometry. Higher Mo-Mo shells exhibited a decrease in amplitude representing an increased dispersion of Mo oxide species on SBA-15 after thermal treatment. The pronounced peak at $\sim 3 \AA$ in the $\mathrm{FT}\left(\chi(\mathrm{k}) \cdot \mathrm{k}^{3}\right)$ of dehydrated $\mathrm{Mo}_{\mathrm{x}} \mathrm{O}_{\mathrm{y}} / \mathrm{SBA}-15$ is indicative of persisting Mo-Mo distances of dimeric or oligomeric $\mathrm{Mo}_{\mathrm{x}} \mathrm{O}_{\mathrm{y}}$ species supported on SBA-15. Hence, the presence of merely isolated tetrahedral $\mathrm{MoO}_{4}$ units in dehydrated $\mathrm{Mo}_{\mathrm{x}} \mathrm{O}_{\mathrm{y}} / \mathrm{SBA}-15$ can be excluded.

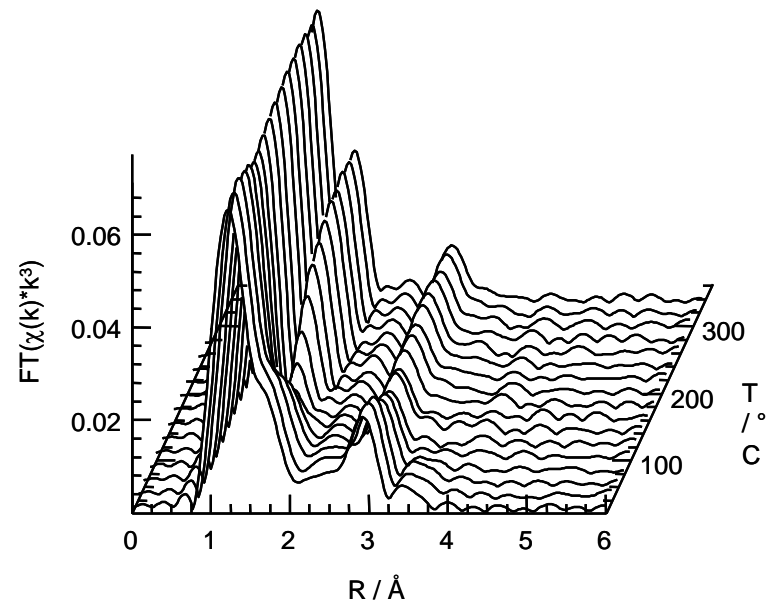

Fig. 6: Evolution of Mo $\mathrm{K}$ edge $\mathrm{FT}\left(\chi(\mathrm{k}) \cdot \mathrm{k}^{3}\right)$ of $\mathrm{Mo}_{\mathrm{x}} \mathrm{O}_{\mathrm{y}} / \mathrm{SBA}-15$ with $5.5 \mathrm{wt} \% \mathrm{Mo} ; 0.6 \mathrm{Mo} / \mathrm{nm}^{2}$ during thermal treatment in $5 \%$ oxygen in $\mathrm{He}$ in the temperature range from $27^{\circ} \mathrm{C}$ to $350^{\circ} \mathrm{C}(5$ $\mathrm{K} / \mathrm{min}$ ). 

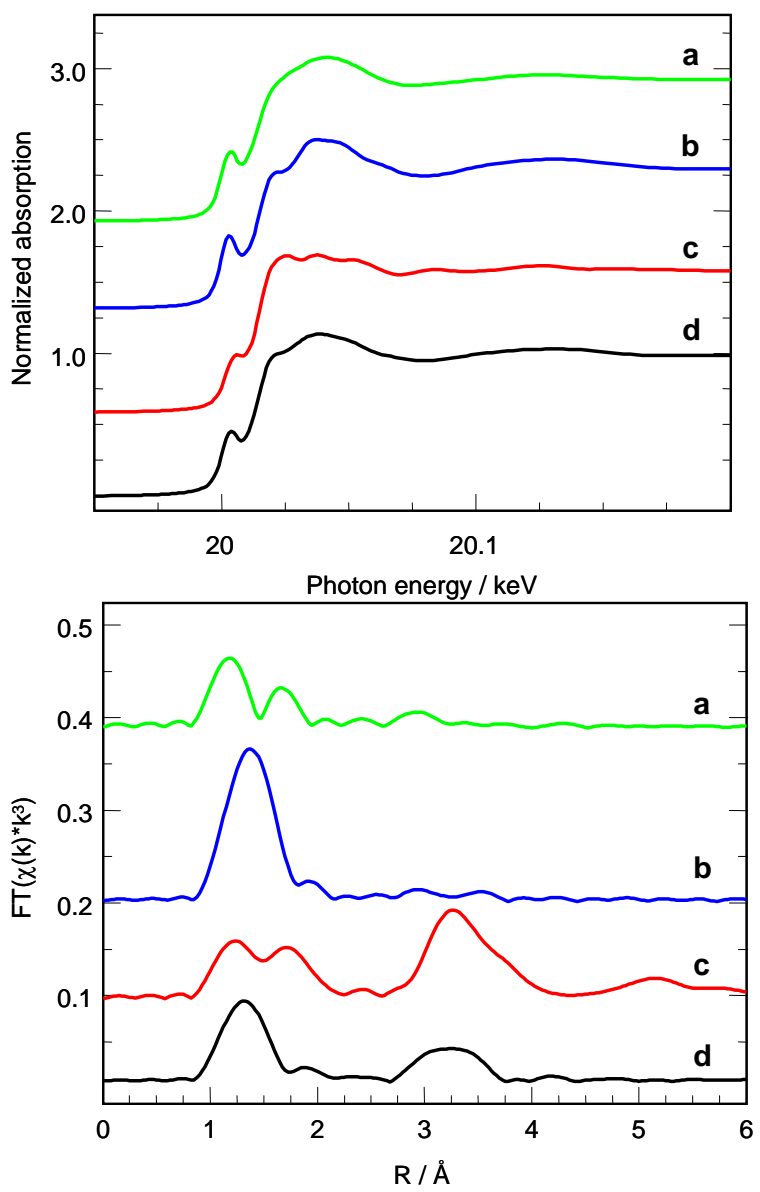

Fig. 7: Mo $\mathrm{K}$ edge XANES spectra (top) and Mo $\mathrm{K}$ edge $\mathrm{FT}\left(\chi(\mathrm{k}) \cdot \mathrm{k}^{3}\right)$ (bottom) of (a) dehydrated $\mathrm{Mo}_{\mathrm{x}} \mathrm{O}_{\mathrm{y}} / \mathrm{SBA}-15$ (5.5 wt $\%$ $\mathrm{Mo} ; 0.6 \mathrm{Mo} / \mathrm{nm}^{2}$ ) together with reference oxides (b) $\mathrm{Na}_{2} \mathrm{MoO}_{4}$, (c) $\alpha-\mathrm{MoO}_{3}$, (d) $\mathrm{Na}_{2} \mathrm{Mo}_{2} \mathrm{O}_{7}$. The spectra are offset for clarity.

The Mo K XANES and $\mathrm{FT}\left(\chi(\mathrm{k}) \cdot \mathrm{k}^{3}\right)$ of dehydrated $\mathrm{Mo}_{\mathrm{x}} \mathrm{O}_{\mathrm{y}} / \mathrm{SBA}-15$ are compared to those of selected reference oxides in Fig. 7, respectively. The Fourier transformed XAFS $\chi(\mathrm{k}) \cdot \mathrm{k}^{3}$ are not phase shift corrected. Thus, the distances in the $\mathrm{FT}\left(\chi(\mathrm{k}) \cdot \mathrm{k}^{3}\right)$ are shifted by $\sim 0.4 \AA$ to lower values compared to the crystallographic distances. The XANES spectrum of hydrated $\mathrm{Mo}_{\mathrm{x}} \mathrm{O}_{\mathrm{y}} / \mathrm{SBA}-15$ is similar to that of $\mathrm{MoO}_{3}$ as has been reported earlier [15]. The XANES of dehydrated $\mathrm{Mo}_{\mathrm{x}} \mathrm{O}_{\mathrm{y}} / \mathrm{SBA}-15$ exhibited an increased pre-edge peak similar to the XANES spectra of references $\mathrm{Na}_{2} \mathrm{MoO}_{4}$ or $\mathrm{Na}_{2} \mathrm{Mo}_{2} \mathrm{O}_{7}$ (see Fig. 7, top). Compared to those references, which contain tetrahedral $\mathrm{MoO}_{4}$ building blocks, the XANES spectrum of dehydrated $\mathrm{Mo}_{\mathrm{x}} \mathrm{O}_{\mathrm{y}} / \mathrm{SBA}-15$ indicates a contribution from tetrahedrally coordinated Mo centres in the Mo oxide species supported on SBA-15. The $\mathrm{FT}\left(\chi(\mathrm{k}) \cdot \mathrm{k}^{3}\right)$ of dehydrated $\mathrm{Mo}_{\mathrm{x}} \mathrm{O}_{\mathrm{y}} / \mathrm{SBA}-15$ shows a pronounced splitting of the first Mo-O shell and significant amplitude at higher Mo-Mo shells (see Fig. 7, bottom). Conversely, the $\mathrm{FT}\left(\chi(\mathrm{k}) \cdot \mathrm{k}^{3}\right)$ of $\mathrm{Na}_{2} \mathrm{MoO}_{4}$ which contains merely $\mathrm{MoO}_{4}$ building units shows a single Mo-O peak and hardly any signal at Mo-Mo distances. Apparently, the characteristic $\mathrm{FT}\left(\chi(\mathrm{k}) \cdot \mathrm{k}^{3}\right)$ of dehydrated

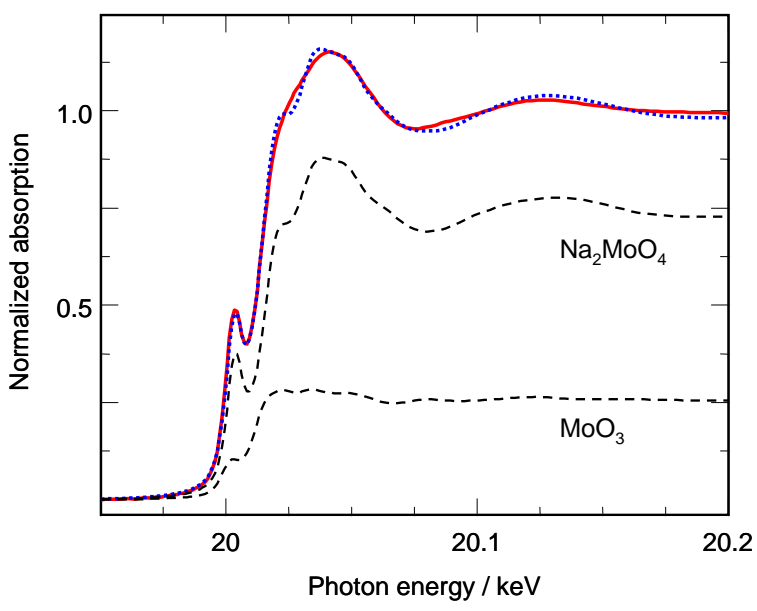

Fig. 8: Refinement of sum (dotted) of XANES spectra of references $\mathrm{MoO}_{3}$ and $\mathrm{Na}_{2} \mathrm{MoO}_{4}$ (dashed) to Mo K edge XANES spectrum of dehydrated $\mathrm{Mo}_{\mathrm{x}} \mathrm{O}_{\mathrm{y}} / \mathrm{SBA}-15$ with $5.5 \mathrm{wt} \%$ Mo-loading; 0.6 $\mathrm{Mo} / \mathrm{nm}^{2}$ (solid).

$\mathrm{Mo}_{\mathrm{x}} \mathrm{O}_{\mathrm{y}} / \mathrm{SBA}-15$ originates from a mixture of polymeric $\mathrm{Mo}_{\mathrm{x}} \mathrm{O}_{\mathrm{y}}$ species and $\mathrm{MoO}_{4}$ tetrahedrons.

Assuming a Mo oxide phase mixture present on the SBA-15 support, a XANES simulation using XANES spectra of appropriate references was attempted. Figure 8 shows the result of a refinement of the sum of the XANES spectra of $\mathrm{MoO}_{3}$ and $\mathrm{Na}_{2} \mathrm{MoO}_{4}$ to that of dehydrated $\mathrm{MoO}_{\mathrm{x}}-\mathrm{SBA}$ 15. A very good agreement in the pre-edge region can be seen, whereas the nearly featureless post-edge region of dehydrated $\mathrm{Mo}_{\mathrm{x}} \mathrm{O}_{\mathrm{y}} / \mathrm{SBA}-15$ is not matched as good. Not surprisingly, the long-range ordered references are less suited to simulate the XANES of the disordered and dispersed dehydrated Mo oxide species supported on SBA-15. Nevertheless, using the pre-edge peak height suffices to quantify the contribution of tetrahedral $\mathrm{MoO}_{4}$ units and distorted $\mathrm{MoO}_{6}$ units. The analysis resulted in a ratio of 3 : 1 for $\mathrm{MoO}_{4}: \mathrm{MoO}_{6}$ units.

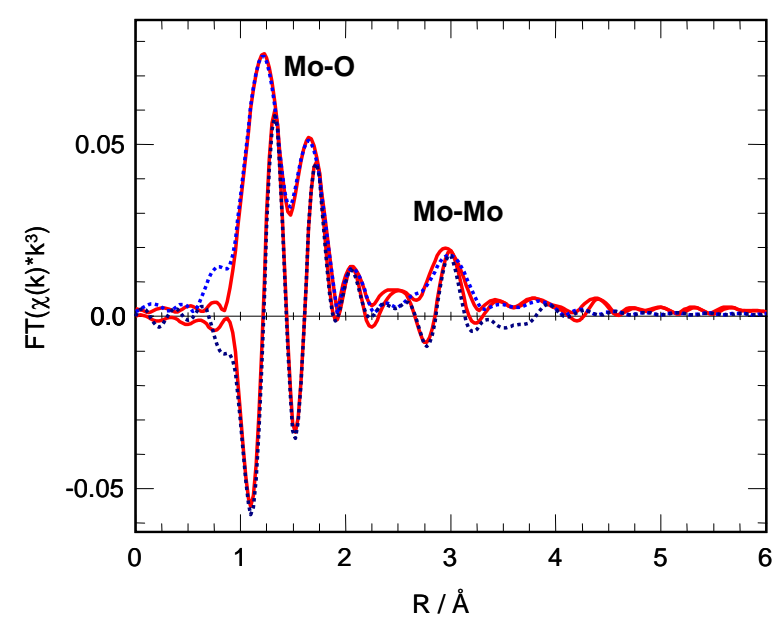

Fig. 9: Experimental and theoretical (dotted) Mo $\mathrm{K}$ edge $\mathrm{FT}\left(\chi(\mathrm{k}) * \mathrm{k}^{3}\right)$ of dehydrated $\mathrm{Mo}_{\mathrm{x}} \mathrm{O}_{\mathrm{y}} / \mathrm{SBA}-15$ with $5.5 \mathrm{wt} \% \mathrm{Mo}-$ loading; $0.6 \mathrm{Mo} / \mathrm{nm}^{2}$. Mo-O and Mo-Mo distances are indicated. 
Table 2: Type, number $(\mathrm{N})$, and XAFS disorder parameters $\left(\sigma^{2}\right)$ of atoms at distance $\mathrm{R}$ from the Mo atoms in $\mathrm{Mo}_{\mathrm{x}} \mathrm{O}_{\mathrm{y}}$ species in dehydrated $\mathrm{Mo}_{\mathrm{x}} \mathrm{O}_{\mathrm{y}} / \mathrm{SBA}-15$. Experimental parameters were obtained from a refinement of a hexagonal $\mathrm{MoO}_{3}$ model structure to the experimental Mo K edge XAFS $\chi(\mathrm{k})$ of dehydrated $\mathrm{Mo}_{\mathrm{x}} \mathrm{O}_{\mathrm{y}} / \mathrm{SBA}$ 15 (Fig. 10) (k range from 3.6 to $14.4 \AA^{-1}$, R range from 0.9 to 4.0 $\AA, \mathrm{E}_{0}=8.0 \mathrm{eV}$, residual $\sim 10.6, \mathrm{~N}_{\text {ind }}=23, \mathrm{~N}_{\text {free }}=13$ ). Confidence limits in distances and $\sigma^{2}$ parameters are indicated. Subscript $\mathrm{C}$ indicates parameters that were correlated in the refinement.

\begin{tabular}{|c|c|c|c|}
\hline Type & $N$ & $R[A]$ & $\sigma^{2}\left[A^{2}\right]$ \\
\hline$M b-0$ & 2 & $1.67 \pm 0.000$ & $0,0010 \pm 0,0001$ \\
\hline Mo-O & 2 & $1.87 \pm 0.005$ & $0.0029 \pm 0.0002$ \\
\hline Mo-O & 1 & $2.25 \pm 0016$ & 0,0029 \\
\hline Ma-O & $i$ & $2.41 \pm 0.000$ & $0.0025 \pm 0.0009$ \\
\hline Mo-Mo & 2 & $3.52=0.012$ & $0,0060 \pm 0,001$ \\
\hline Mo-Mo & 2 & $3.67 \pm 0.014$ & 0.0060 \\
\hline Mo-Mo & 2 & $3.82 \pm 0.019$ & $0.0101 \pm 0,002$ \\
\hline
\end{tabular}

Eventually, the local structure around the Mo centres in dehydrated $\mathrm{Mo}_{\mathrm{x}} \mathrm{O}_{\mathrm{y}} / \mathrm{SBA}-15$ (5.5 wt $\%$ Mo) was determined by detailed EXAFS analysis. While seeking a suitable model system to simulate the experimental $\mathrm{FT}\left(\chi(\mathrm{k}) \cdot \mathrm{k}^{3}\right)$ of dehydrated $\mathrm{Mo}_{\mathrm{x}} \mathrm{O}_{\mathrm{y}} / \mathrm{SBA}-15$ it became apparent, that one or two Mo-Mo distances were not sufficient. Despite of the reduced amplitude at higher shells (see Fig. 9), three MoMo distances were required to account for the particularshape of the amplitude and imaginary part of the $\mathrm{FT}\left(\chi(\mathrm{k}) \cdot \mathrm{k}^{3}\right)$ of dehydrated $\mathrm{Mo}_{\mathrm{x}} \mathrm{O}_{\mathrm{y}} / \mathrm{SBA}-15$ in the range between 2.5 and $3.5 \AA$. Therefore, theoretical phases and amplitudes calculated for various Mo-O and three Mo-Mo distances in reference hexagonal $\mathrm{MoO}_{3}$ were used for EXAFS refinement. Theoretical and experimental Mo $\mathrm{K}$ edge $\mathrm{FT}\left(\chi(\mathrm{k}) \cdot \mathrm{k}^{3}\right)$ of dehydrated $\mathrm{Mo}_{\mathrm{x}} \mathrm{O}_{\mathrm{y}} / \mathrm{SBA}-15$ are shown in Fig. 9. Structural parameters obtained from the XAFS refinement are given in Table 2.

The results presented above demonstrate the potential of combining Raman-, UV-Vis and X-ay absorption spectroscopy to study the structure of silica SBA-15 supported highly dispersed molybdenum oxide. On the one hand, the Raman spectra reveal the absence of crystalline molybdenum oxide phases (e.g. $\alpha-\mathrm{MoO}_{3}$ ) with high sensitivity, whereas minority molybdenum oxide phases $(<5$ $\mathrm{wt} \%)$ are difficult to detect by UV-Vis and XAS. On the other hand, the UV-Vis and in particular the XAS results clearly show that connected molybdenum oxide centres are present even at low Mo densities in the dehydrated state, while the visible Raman spectra (514 nm excitation) do not allow for a differentiation between isolated and oligomeric species. Besides, by XAS both tetrahedrally and octahe- drally coordinated $\mathrm{MoO}_{4}$ and $\mathrm{MoO}_{6}$ units are identified. The $\mathrm{MoO}_{6}$ units possess connectivity similar to that of $\mathrm{MoO}_{3}$ building blocks, whereas the $\mathrm{MoO}_{4}$ units are isolated or connected to other $\mathrm{Mo}_{\mathrm{x}} \mathrm{O}_{\mathrm{y}}$ units. Scheme 1 summarizes the findings of this study regarding the structure of silica SBA-15 supported molybdenum oxide in its dehydrated state at low Mo loadings i.e. at loadings at which no $\mathrm{MoO}_{3}$ is present. Most importantly, the molybdenum oxide surface species consist of a mixture of monomeric and connected molybdenum oxide centres. Very recently, the use of TOF-SIMS as an alternative experimental approach to differentiate between isolated and connected molybdenum oxide species was demonstrated for alumina and mixed silica/alumina supported molybdenum oxide $[67,68]$.

\section{Conclusions}

A series of silica SBA-15 supported molybdenum oxides samples in a loading range of 1.0 to $13.9 \mathrm{wt} \% \mathrm{Mo}$ ( 0.2 to $6.8 \mathrm{Mo} / \mathrm{nm}^{2}$ ) has been examined by visible Raman spectroscopy, diffuse reflectance UV-Vis spectroscopy and $\mathrm{X}$-ray absorption spectroscopy in its dehydrated state after pre-treatment in synthetic air at temperatures $\geq 350^{\circ} \mathrm{C}$. The results show that at low Mo densities $\left(\leq 0.8 \mathrm{Mo} / \mathrm{nm}^{2}\right)$ the surface molybdenum oxide structures do not depend on the preparation procedure. While the presence of crystalline $\mathrm{MoO}_{3}$ can be excluded the dehydrated molybdenum oxide surface species at low loadings is found to be composed of both di- or oligomeric molybdenum oxide centres and isolated centres. Furthermore, XAS reveals that a mixture of tetrahedrally and octahedrally coordinated $\mathrm{MoO}_{4}$ and $\mathrm{MoO}_{6}$ centres is present.

\section{Acknowledgement}

The authors like to thank HASYLAB, Hamburg for providing beamtime for this work and Gisela Lorenz at the Fritz-Haber-Institut in Berlin for performing the $\mathrm{N}_{2}$ adsorption-desorption experiments. Furthermore the authors thank Prof. Robert Schlögl for fruitful discussions and financial support.

\section{References}

[1] M.A. Banares, H. Hu, I.E. Wachs, J. Catal. 150 (1994) 407.

[2] W. Zhang, S.T. Oyama, J. Phys. Chem. 100 (1996) 10759.

[3] H. Lu, E. Iglesia, J. Catal. 208 (2002) 1.

[4] M.A. Banares, N.D. Spencer, M.D. Jones, I.E. Wachs, J. Catal. 146 (1994) 204.

[5] K. Chen, A.T. Bell, E. Iglesia, J. Catal. 209 (2002) 35.
[6] Z. Song, N. Mimura, J.J. Bravo-Suarez, T. Akita, S. Tsubota, S.T. Oyama, Appl. Catal. A 316 (2007) 142.

[7] J. Handzlik, J. Ogonowski, R. Dula, J. Stoch, E.M. Serwicka, React. Kinet. Catal. Lett. 79 (2003) 135.

[8] J. Handzlik, J. Phys. Chem. B 109 (2005) 20794.

[9] J.J.P. Biermann, F.J.J. Janssen, J.R.H. Ross, Appl. Catal. A 86 (1992) 165. 
[10] I. Nova, L. Lietti, L. Casagrande, L. Dall'Acqua, E. Giamello, P. Forzatti, Appl. Catal. B 17 (1998) 245.

[11] A.N. Desikan, W. Zhang, S.T. Oyama, J. Catal. 157 (1995) 740.

[12] G. Tsilomelekis, A. Christodoulakis, S. Boghosian, Catal. Today 127 (2007) 139.

[13] T. Ono, H. Kamisuki, H. Hisashi, H. Miyata, J. Catal. 116 (1989) 303.

[14] M.A. Banares, H. Hu, I.E. Wachs, J. Catal. 155 (1995) 249.

[15] T. Ressler, A. Walter, Z.-D. Huang, W. Bensch, J. Catal. 254 (2008) 170.

[16] Z. Huang, W. Bensch, W. Sigle, P.A. van Aken, L. Kienle, T. Vitoya, H. Modrow, T. Ressler, J. Mater. Sci. 43 (2008) 244.

[17] Y. Lou, H. Wang, Q. Zhang, Y. Wang, J. Catal. 247 (2007) 245

[18] P.C. Bakala, E. Briot, L. Salles, J.M. Brégeault, Appl. Catal. A 300 (2006) 91.

[19] J.A. Melero, J. Iglesias, J.M. Arsuaga, J. Sainz-Pardo, P. de Frutos, S. Blazquez, Appl. Catal. A 331 (2007) 84

[20] H. Balcar, D. Mishra, E. Marceau, X. Carrier, N. Zilkova, Z. Bastl, Appl. Catal. A 359 (2009) 129.

[21] J.P. Thielemann, J. Kröhnert, C. Hess, J. Phys. Chem. C 114 (2010) 17092

[22] H. Hu, I.E. Wachs, S.R. Bare, J. Phys. Chem. 99 (1995) 10897.

[23] C.C. Williams, J.G. Ekerdt, J.M. Jehng, F.D. Hardcastle, A.M. Turek, I.E. Wachs, J. Phys. Chem. 95 (1991) 8781.

[24] S. Chempath, Y. Zhang, A.T. Bell, J. Phys. Chem. C 111 (2007) 1291

[25] N. Ohler, A.T. Bell, J. Phys. Chem. B 110 (2006) 2700.

[26] N. Ohler, A.T. Bell, J. Phys. Chem. B 109 (2005) 23419.

[27] E.L. Lee, I.E. Wachs, J. Phys. Chem. C 112 (2008) 6487.

[28] Y. Iwasawa, K. Asakura, H. Ishii, H. Kuroda, Z. Phys. Chem. 144 (1985) 105

[29] Y. Iwasawa, Adv. Catal. 35 (1987) 265

[30] Y.V. Plyuto, I.V. Babich, I.V. Plyuto, A.D. Van Langeveld, J.A. Moulijn Coll. Surf. A 125 (1997) 225.

[31] E.L. Lee, I.E. Wachs, J. Phys. Chem. C 111 (2007) 14410.

[32] C. Hess, ChemPhysChem 10 (2009) 319.

[33] A. Walter, R. Herbert, C. Hess, T. Ressler, Chem. Central J. 4 (2010) 3.

[34] C. Hess, U. Wild, R. Schlögl, Microp. Mesop. Mat. 95 (2006) 339.

[35] M. Cavalleri, K. Hermann, A. Knop-Gericke, M. Hävecker, R. Herbert, C. Hess, A. Oestereich, J. Döbler, R. Schlögl, J. Catal. 262 (2009) 215.

[36] T.V. Venkov, C. Hess, F.C. Jentoft, Langmuir 23 (2007) 1768.

[37] D.Y. Zhao, J.L. Feng, Q.S. Huo, N. Melosh, G.H. Fredrickson, B.F. Chmelka, G.D. Stucky, Science 279 (1998) 548.

[38] D. Zhao, Q. Huo, J. Feng, B.F. Chmelka, G.D. Stucky, J. Am. Chem. Soc. 120 (1998) 6024.

[39] C. Hess, J.D. Hoefelmeyer, T.D. Tilley, J. Phys. Chem. B 108 (2004) 9703.
[40] S. Brunauer, P.H. Emmett, E. Teller, J. Am. Chem. Soc. 60 (1938) 309

[41] L. Jelinek, E. Kováts, Langmuir 10 (1994) 4225.

[42] T. Ressler, J. Synch. Rad. 5 (1998) 118.

[43] J.J. Rehr, C.H. Booth, F. Bridges, S.I. Zabinsky, Phys. Rev. B 49 (1994) 12347

[44] T. Ressler, S.L. Brock, J. Wong, S.L. Suib, J. Phys. Chem. B 103 (1999) 6407.

[45] http://www.ixasportal.net/ixas/images/ixas mat/StandardsCrite ria July25 2000.pdf (accessed 2/1/2010).

[46] Numerical Recipes: The Art of Scientific Computing, Third Edition (2007), Cambridge University Press (www.nr.com).

[47] R. Herbert, D. Wang, R. Schomäcker, R. Schlögl, C. Hess, ChemPhysChem 10 (2009) 2230.

[48] T.M. McEvoy, K.J. Stevenson, Langmuir 21 (2005) 3521.

[49] The small signal at $422 \mathrm{~cm}^{-1}$ originates from the sample holder.

[50] C.J. Brinker, R. Kirkpatrick, D.R. Tallant, B.C. Bunker, B. Montez, J. Non-Cryst. Solids 99 (1988) 418.

[51] D.R. Tallant, B.C. Bunker, C.J. Brinker, C.A. Balfe, Mater. Res. Soc. Symp. Proc. 73 (1986) 261.

[52] B.C. Brinker, D.R. Tallant, E.P. Roth, C.S. Ashley, Mater Res. Soc. Symp. Proc. 61 (1986) 387.

[53] R.H. Stolen, G.E. Walrafen, J. Chem. Phys. 64 (1986) 2623.

[54] M. de Boer, A.J. van Dillen, D.C. Koningsberger, J.W. Geus, M.A. Vuurman, I.E. Wachs, Catal. Lett. 11 (1991) 227.

[55] C.C. Williams, J.G. Ekerdt, J.M. Jehng, F.D. Hardcastle, A.M. Turek, I.E. Wachs, J. Phys. Chem. 95 (1991) 8781.

[56] I.G. Shenderovich, G. Buntkowsky, A. Schreiber, E. Gedat, S Sharif, J. Albrecht, N.S. Golubev, G.H. Findenegg, H.H. Limbach, J. Phys. Chem. B 107 (2003) 11924.

[57] L.J. Gregoriades, J. Döbler, J. Sauer, J. Phys. Chem. C 114 (2010) 2967.

[58] The change in intensity ratio was observed during treatment of $\mathrm{Mo}_{\mathrm{x}} \mathrm{O}_{\mathrm{y}} / \mathrm{SBA}-15\left(2.0 \mathrm{Mo} / \mathrm{nm}^{2}\right)$ in synthetic air $\left(\mathrm{O}_{2} / \mathrm{N}_{2} / \mathrm{H}_{2} \mathrm{O}\right.$ $=10 / 90 / 0)$ at $500^{\circ} \mathrm{C}$ and switching to an atmosphere containing a high amount of steam $\left(\mathrm{O}_{2} / \mathrm{N}_{2} / \mathrm{H}_{2} \mathrm{O}=10 / 45 / 45\right)$.

[59] R.K. Rana, B. Viswanathan, Catal. Lett. 52 (1998) 25.

[60] S. Higashimoto, Y .Hua, R. Tsumura, K. Iino, M. Matsuoka, H. Yamashita , Y.G. Shul, M. Che, M. Anpo J. Catal. 235 (2005) 272.

[61] J.Y. Piquemal, J.-M. Manoli, P. Beaunier, A. Ensuque, P. Tougne, A.P. Legrand, J.M. Bregeault, Microp. Mesop. Mat. 29 (1999) 291

[62] M. Fournier, C. Louis, M. Che, P. Chaquin, D. Masure, J. Catal. 119 (1989) 400 and references therein.

[63] H. Jezlorowski, H. Knözinger, J. Phys. Chem. 83 (1979) 1166.

[64] S.R. Seyedmonir, R.F. Howe, J. Catal. 110 (1989) 216.

[65] C.N. Asmolov, O.V. Krylov, Kim. Katal. 11 (1970) 1028.

[66] M. Matsuoka, T. Kamegawa, R. Takeuchi, M. Anpo, Catal. Today 122 (2007) 39.

[67] J. Grams, Eur. J. Mass Spectrom. 16 (2010) 453.

[68] D.P. Debecker, B. Schimmoeller, M. Stoyanova, C. Poleunis, P. Bertrand, U. Rodemerck, E.M. Gaigneaux, J. Catal. 277 (2011) 154 